\title{
Political Power and Social Inequalities in Memory and Oblivion
}

\section{Stefan Peters}

Yo no me acuerdo, no me acuerdo

$Y$ si no me acuerdo

No pasó, eso no pasó ${ }^{1}$

Thalía und Natty Natasha

Not only in Reggaeton: Forgetting is en vogue! The question of forgetting on the Internet is discussed just as centrally in the cultural pages of daily newspapers as the challenges of caring for dementia patients in an ageing society. But beyond that, forgetting has experienced an unexpected revival in recent years. Already almost a decade ago, a new "conjuncture of forgetting" (Dimbath \& Wehling, 2011: 8) was noted in the debates on collective memory. In part, this goes hand in hand with the intention of shifting the political direction of the past. According to a growing number of voices, the memory of past violence does not allow the wounds of a violent past to heal, but rather perpetuates social rifts and polarization, or even contains the seeds of future (violent) conflicts.

This position stands in remarkable contrast to the hard-won consensus on the value of memory as part of dealing with the violent legacy of dictatorships, civil wars and massive human rights violations. In so doing, it also opposes the importance of collective memory as a condition sine qua non on the way to preventing the recurrence of such acts of violence. To avoid misunderstandings: the imperative of memory remains widespread and is based on a solid foundation. This could be observed, for instance, on the occasion of the 75th anniversary of the liberation of the former concentration and extermination camp in Auschwitz. ${ }^{2}$ But it is not restrict-

1 Lyrics by the Duo Thalía and Natti Natasha from the song "No me acuerdo" (English: I don't remember) from the genre of Reggaeton. English: "I don't remember and if I don't remember it didn't happen, this didn't happen.”

2 Federal President Frank-Walter Steinmeier said on this occasion: "Auschwitz - a place of terror and a place of German guilt. We know what Germans did to others, but we struggle for words to describe the extent of the horror. The times are 
ed to Europe and the memory of the atrocities committed by the Nazis. The generalized consensus on the value of memory is, for example, also manifested in Latin America in current debates on dealing with the past of dictatorship and civil wars. In addition, there are a large number of representations of the past in the culture of remembrance, each of which makes it its task to deal with history and often also - at least in part - has educational intentions (Jelin, 2015). ${ }^{3}$

Despite the ubiquity of memories in political and cultural interventions in the public arena, ${ }^{4}$ the imperative of remembering the past is being increasingly torn apart. In some cases, arguing in favor of forgetting is already a socially acceptable position. In striking contrast to the optimism of the majority of research on collective remembrance with regard to the

different today, the words are different, the deeds are different. But sometimes, when we look back into those times, I have the impression that the evil is still there, the evil is the same. And that is why here in Auschwitz we do not only talk about the past, but also see it as an enduring responsibility to resist the beginnings, also in our country" (https://www.bundespraesident.de/SharedDocs/Berichte/DE/F rank-Walter-Steinmeier/2020/01/200127-Reise-Polen-Auschwitz-Gedenken.html).

3 Increasingly, (new) forms of (popular) cultural communication of historical content are also being used. These include TV series, graphic novels and video games. The latter includes, for example, the German-language game Through the Darkest of Times, in which the player leads a resistance movement in Berlin during the $\mathrm{Na}$ tional Socialist era and has to make moral decisions time and again. Moreover, in the current Colombian Peace Process, there are initiatives to use eduentertainment in order to get discussions on the past atrocities to a broader audience.

4 For analytical purposes, a distinction can be made between the politics of the past and the culture of remembrance in researching processes of remembrance. The politics of the past refers to the public construction of interpretations of violent and traumatic events of the past (Bock \& Wolfrum, 1999; Kohlstruck, 2004). In particular, it refers to the state's administrative handling of the past and the conflicts and discussions associated with it. The actors in politics concerning the past use privileged political and/or social positions to transmit their interpretations of the past within society. In addition to laws, political speeches, the setting of days of remembrance, the financing and construction of monuments, museums or memorials, the media of Vergangenheitspolitik also include the establishment of official readings of history, e.g. in curricula, textbooks, truth commissions and court rulings. In contrast, the term refers to the manifold social, political and cultural articulations of memory. To this end, the culture of remembrance relies on a variety of different media: literature (novels, poems, plays and their stagings), music, (documentary) films and various forms of art. High-priced paintings are just as much a part of this as everyday caricatures or subcultural forms of street art or graffiti interventions. This is supplemented by memory rituals, political actions of social movements or civil society groups, readings, exhibitions or public articulations in letters to the editor, blogs and commentary columns. 
politics of the past, forgetting as a mechanism to avoid social conflict is once again being broached - in line with the reggaeton lines quoted at the beginning.

This turn towards forgetting appears to be a journey back to the future. Therefore, it is no coincidence that Christian Meier (2010), a historian of ancient history, is the key figure in the German-speaking world for the revaluation of forgetting. Meier refers back to the ancient Greeks more precisely to the Athenian amnesty in the years 404/403 B.C. - to develop his thesis on the healing power of forgetting. In fact, Meier cites further examples from the history of the Roman Empire, but also from post-revolutionary France, to support his argument of the importance of forgetting for maintaining social cohesion. While Meier presents his theses cautiously and prudently and allows exceptions - for example, with regard to Holocaust remembrance - the US-American journalist David Rieff $(2011$; 2016) takes the same line with essayistic charm and pointed exaggerations. In essence, both authors argue that the memory of past violence and human rights violations is in constant danger of tearing open the wounds of the past and thus undermining the successful consolidation of democratisation or post-conflict processes. In contrast, only (temporary) forgetting can guarantee harmonious or at least peaceful social coexistence. The authors thus recycle arguments that already justified the silence pacts and amnesties in Spain and the Southrern Cone during the transitions of the 1970s and 1980s (Aguilar, 2002; Fuchs, 2010; Lessa, 2011). But it was only when Meier and Rieff brought the issue to a head that this position received a great deal of attention in the academic world and, above all, in the arts pages and in politics.

This article analyses this new attention to forgetting in research on collective memory and argues that forgetting, like memory, must always be thought of in the plural. Consequently, there are different forms of forgetting, which are briefly presented. The focus is then shifted to collective forgetting or hushing up ${ }^{5}$ events or contexts of the past and the concept of (non-)memory is introduced, before (non-)memory is finally dealt with in greater depth using case studies from Latin America and Europe.

5 The term 'hushing up' is used here in reference to the debates on dealing with the past in Germany as a mostly conscious non-topicisation of the past (Lübbe, 1983; see also: Assmann, 2012: 58). 


\section{Dealing with the past between remembering and forgetting}

In large parts of (European) history, for a long time forgetting rather than remembering the painful past was the rule (Meier, 2010). ${ }^{6}$ This is also reflected in the classic texts on collective memory: Maurice Halbwachs, one of the pioneers of research on collective memory, has dedicated himself in his texts not only to remembering but also to forgetting. In his famous lecture "Qu'est- ce qu'une nation?" from 1882, the French intellectual Ernest Renan also emphasized that the construction of a nation is not only based on shared memories, but always on forgetting a part of violent history (Renan, 1995: 45f.). But that is not enough: the deliberate forgetting of the (violent) conflicts of the past must also be forgotten (Castiñeira, 2005: 65).

This hegemony of repressing and forgetting the painful past was only seriously shaken in the second half of the 20th century. Since then, a veritable "boom of memory" has been observed in many regions of the world (Bernecker \& Brinkmann, 2006; Hite, 2017: 191). This boom often emanated from civil society initiatives, the arts and/or culture. In terms of dealing with the crimes of the Nazis, it was not the Nuremberg Trials or the Frankfurt Auschwitz Trial that broke the social silence about the crimes of the past. Rather, it was the social conflicts surrounding the 1968 movement, the impact of the TV series 'Holocaust', the work of the countless civil society local history groups (Geschichtswerkstätten) and various cultural and artistic projects that brought the memory of the crimes of the past into broad sections of society with some delay. Forgetting became increasingly disreputable and at the same time the remembrance of the crimes of the past was gradually declared a civic or at least a civil society duty.

The way the past is dealt with is often ascribed magical but rather unrealistic abilities. A frequently quoted phrase is a good example of this: 'Those who cannot remember the past are condemned to repeat it'. This phrase is usually attributed to the philosopher George Santayana and has long been widely accepted without question. As a result, the often-painful process of dealing with the past uses to be presented as a 'guarantee of non-repetition'. On the one hand, this has a calming effect on the academic discipline of history, whose socio-political relevance is strengthened by the bon mot and its implications. On the other hand, this position is also

6 This was accompanied by a heroic remembrance of past battles, which were usually important as national myths for the construction of nations and were immortalized in national history, monuments and museums. 
extremely attractive for practical politics: a comprehensive examination of the past becomes an effective vaccine against anti-democratic regression.

In many Latin American countries, a similar development towards a "duty to remember" can be observed increasingly (Jelin, 2002). Although powerful voices in Latin America argued for forgetting the past, to stop looking backwards and therefore forgetting the atrocities of the past, ultimately this position was increasingly rejected. Regarding collective memory from the 1980s onwards, initially the memory of the civil-military dictatorships of the Southern Cone was the focus of attention. Of central importance here was the Argentinean case, where the demand Nunca Más (Never Again) became a powerful slogan for dealing with the past as a prerequisite for non-repetition and against forgetting and was soon taken up by human rights organisations in other contexts in the region. Since the beginning of the 1990s, this has been complemented by a turn to remembering colonisation and the violence of the civil wars in Central America, Peru and Colombia. The remembrance of the past was by no means a harmonious process but was itself the subject of fierce social and political conflicts. Various publications analysed not only the political and social conflicts between different social groups but also within human rights organisations regarding the interpretation and representation of the past in the present (Allier Montaño, 2010; Fuchs, 2010; Lessa, 2014; Allier \& Crenzel, 2016; Olaso, 2016; Jelin, 2017; Alarcón, 2020). The multiplicity and plurality of the memory actors involved is the reason for the polyphony of historical interpretations within a society. This heterogeneity of interpretations of the past, which can result from different political positions, ideologies, interests or social positioning in the present, not only makes it difficult to reach a social consensus on the assessment of historical figures, processes and epochs, but also proves to be a fruitful source of political and social mobilisations for or against certain policies on the past, interpretations of history and/or narratives of memory. These "political struggles for memory" (Jelin, 2002: 39) in turn feed the dynamics of interpretations of the past and guarantee that memories and interpretations of history are not static but in a state of permanent change.

At the international level, Latin America soon became a central reference point for research on dealing with the past of massive human rights violations in the context of civil wars and dictatorships. This was due on the one hand to the dynamics of the region's politics of the past and its culture of memory, and - closely related to this - to various theoretical and conceptual impulses for academic debate. On the other hand, Latin America also became a fixed point for practical transitional justice debates. The various instruments of Transitional Justice - legal processing and/or 
truth commissions, compensation, etc. - soon became a kind of gold standard for policies dealing with a violent past (Oettler \& Buckley-Zistel, 2011; Figari Layús, Krüger \& Peters, 2021).

Although there is no doubt that the enthusiasm for the politics and culture of remembrance of the past continues, authors and positions that are critical of memory and tend to affirm the healing power of forgetting were widely received and discussed. In the discussion about the role of forgetting, however, it is important to note that there are different forms of forgetting and that this should therefore be thought of in the plural (Cohen, 1995; Ricoeur, 2004; Connerton, 2008; Assmann, 2016). In the following, different types of forgetting will be presented first, followed by a look at a form of forgetting that can be grasped with the concept of (non-)memory (Eser \& Peters, 2016) and includes various reasons for the exclusion of certain narratives of memory from public debate. This form of forgetting, which can occur either as a deliberate act of silencing or as a structurally determined absence of a space of resonance ${ }^{7}$ in the politics and culture of remembrance, will be illustrated with short examples. On this basis, the article ends with reflections on the possibilities and limits of science and culture in making visible such excluded memories.

\section{Thinking about forgetting in the plural}

Forgetting is an everyday phenomenon. This applies to both individual and collective memory. In fact, any construction of (collective) memory is always based on the explicit or implicit exclusion of some elements of the past. As a rule, however, this is not a matter of complete forgetting. Rather, with Aleida Assmann (2016), collective memory can be understood as the staggered space of a shop. Emblematic memories can be found in the shop window, while in the shop itself further memories are constantly recalled. The vast majority of memories are found in the store or archive and are therefore out of sight of the general public and even invisible for most specialists. Nevertheless, they are in principle available to the public for inclusion in the collective memory. However, it is important to keep in mind that the processes of collective memory and forgetting are dynamic. What is in the shop window today can be disposed of in the attic tomor-

7 With Rosa (2016), the concept of resonance here simply refers to the opportunities for communication, without transferring its baggage of the relationship between individual and society to Latin America. 
row and vice versa. ${ }^{8}$ Forgetting is therefore not necessarily permanent or absolute - at the very least, the concept of forgetting is blurred. It should rather be spoken of as silence or lack of resonance, which can be grasped with the concept of (non-)memory.

For research on processes of collective memory, the question of the reasons why certain fragments of memory are banned from public space is of particular importance. To this end, a distinction can be made between different types or forms of forgetting or (non-)memory (Connerton, 2008; Assmann, 2016). ${ }^{9}$ Following and extending Assmann's thesis on the collective memory of violence and human rights violations of the past, five forms of (non-)remembrance gain particular relevance: i) the conscious 'forgetting' of the past as a means of containing socio-political conflicts à la Meier and Rieff; ii) the forgetting or concealment of crimes by the perpetrators; iii) the forgetting or concealment of violent experiences by the victims; iv) an emptying of memory through commercialisation or trivialisation; and v) the forgetting or lack of resonance of the memories of marginalised and/or subaltern groups.

Firstly, conscious forgetting as a protective shield against a supposed resurgence of past conflicts as a mode of social conflict management can be found in a number of examples from the past and present. As already mentioned, German historian Christian Meier already referred back to forerunners from antiquity. However, even in the recent past, the argument of preventing the rupture of old lines of conflict through the 'struggles for memory' (Leggewie, 2011) has lost hardly any political relevance. In the 20th century, the political will to forget the past manifested itself particularly in post-war Germany. After the Nuremberg Trials, the discussion of Nazi crimes was almost completely banned from social debates. The focus of German society was on reconstruction and 'economic growth'; in contrast, an intensive social confrontation with the past seemed of secondary importance or was even perceived as disturbing (Karstedt, 2010: 14p.). ${ }^{10}$ For all the differences between the cases and the crimes, similar arguments can be found in other contexts. The Spanish transition from the dictatorship under Francisco Franco to democracy

8 This is also true for museums. The world's most important museums usually show less of 10 per cent of their collections to the public (https://www.bbc.com/c ulture/article/20150123-7-masterpieces-you-cant-see, 30-09-2020).

9 Psychoanalytic approaches to forgetting are not dealt with in this article.

10 The historian Tony Judt (2005: 61) argues in this respect that without "collective amnesia Europe's astonishing post-war recovery would not have been possible." However, the question remains as to which social groups opted for forgetting. 
was bought by the renunciation of memory in the form of a pact of silence (pacto de silencio), and in Portugal after the Salazar dictatorship, dealing with the past was not initially on the political priority list either. Looking back was seen not least as a danger to successful democratization (Capdepón, 2018). Similar dynamics can also be observed in parts of Latin America. The Spanish example became a role model for Latin America. In Brazil and Uruguay, for instance, memories of past human rights crimes committed by civil-military dictatorships were banned from public discourse. Here, too, it was argued that keeping silent or forgetting the crimes of the past would lay the foundation for stabilizing democracy (Lessa, 2014; Schelotto, 2017).

The perpetrators and their accomplices are - secondly - a central source of forgetting, silencing or concealing the past. This is perfectly legitimate: the right to remain silent and to refuse to testify is undoubtedly one of the pillars of constitutional principles (Förster, 2008: 123). In the context of dealing with the past of massive human rights violations, however, it is at the same time an obstacle to the clarification of the violence of the past and thus also to the practices of remembrance. The practice of transitional justice has taken this dilemma into account in that conditioned amnesties or mechanisms of restorative justice are intended to increase the perpetrators' willingness to testify, so that victims and society in general could gain certainty about the crimes of the past. This calculation can aptly be characterised as "trading justice for the past in exchange for justice in the future" (Roht-Arriazas, 2006: 3). A much-discussed example of this is the South African Truth and Reconciliation Commission for dealing with the crimes of the apartheid regime. It was given quasi-judicial powers and was able to grant the perpetrators legally binding amnesties in exchange for telling the truth (Krüger \& Scheuzger, 2019). Nevertheless, when taking a global perspective, many of the perpetrators insist on their right to remain silent, thus hindering the clarification of the truth about the past, and in the medium and long term they can promote forgetting the crimes.

Thirdly, the silence about the past is by no means limited to the perpetrators and their obvious motives. Often it is precisely the victims who do not want to talk about the suffering they have experienced or who cannot talk about it for psychological, social and/or political reasons. The reasons for this are manifold and range from the presence of violent actors in everyday life and the associated fear of making the crimes public, to feelings of shame regarding the discussion of one's own experiences of violence or the social preference for keeping silent about particularly shameful forms of violence (for example in the case of sexual violence), to questioning the victim's status as a result of a naturalisation of certain patterns of violence 
and the associated concern not to be heard (Pollak, 2006; Karstedt, 2010: 16p.; Wilches, 2010). In this case, one can therefore hardly speak of an active decision to keep the past quiet to a limited extent. But Clair (1998: 162) places the silence of the victims between the poles of oppression and agency. In this respect, Mannergren Selimovic (2020: 11p.) points out that silence can also be an expression of resistance - as a denial of the rules of the memory industry - or that the silent presence of previously displaced persons is a constant non-verbal indictment.

Another form of forgetting is - fourthly - promoted by the commodification of memory. The memory of the past has long been part of a commercialised culture of remembrance. This manifests itself in cultural artefacts (films, novels, songs, etc.) but also in the development of places of remembrance for tourist purposes, known as "dark tourism" (Bajohr, Drecoll \& Lennon, 2020; see also: Alier Montaño, 2018; González Vázquez $\&$ Mundet i Cerdan, 2018). ${ }^{11}$ This reveals an ambivalence in the culture of remembrance. On the one hand, the popularity of the themes allows for a broad impact, and on the other hand, the massive interest in memory runs the risk of encouraging banalisation, which ultimately encourages a form of forgetting despite the omnipresence of the past (Payne \& Bilbija, 2011).

While the aforementioned dynamics of forgetting or hushing up the violent past each involve a decision to refrain from a public discourse on the violence of the past, the fifth form of non-remembrance aims at a forced or power-based exclusion from the public space of remembrance. These are memories that are very present at the level of individuals or social groups and are also endowed with the desire to articulate them. Nevertheless, these articulations of the memory of the violence of the past are denied resonance in the public space for political and/or social reasons (Eser \& Peters, 2016; Rivera Revelo \& Peters, 2017).

Silencing as an expression of power: the two facets of (non-)memory

What the five forms of silence have in common is that, although at first glance non-articulation suggests forgetting, memory actually manifests it-

11 The potential for commercializing the memory of the violent crimes of the past has been recognized, for example, by the International Monetary Fund (IMF) Business School. In a blog entry it says: "Memory tourism is a branch of the tourism industry that is concerned with transforming 'collective and individual memories' into a cultural heritage with tourist appeal” (https://blogs.imf-formacio n.com/blog/mba/tendencias-viajes-turismo-memoria 07-03-2020; own translation). 
self in silence. The (non-)recollection of emblematic events of the past can therefore hardly be interpreted as accidental forgetting. It is rather an actively produced silence and/or a silence due to structural obstacles to resonance in public space, which is actively produced just like memory (Eser \& Peters, 2016). Mirroring the work of memory (Jelin, 2002), a practice of working on forgetting can also be observed.

From this, the academic and political relevance of the analysis of (non-)memory can be deduced. Absent or marginalised memories represent the other side of the coin of socially respected interpretations of the past. ${ }^{12}$ In this sense, silence through (unintentional) exclusion from the public space of memory is of particular interest. This is a consequence of power asymmetries, which are reflected in a different resonance of the articulation of memory narratives in the public space. In other words, it is not a matter of forgetting strictu sensu, but rather of keeping silent about the past. Yet this silence does not necessarily obey the wish of the actors or even the victims. Rather, memories are very present on an individual and/or social level, although there are political and/or social barriers that prevent the corresponding narratives from being thematised in public space. In short: these are memories that exist and can be documented but which cannot find a place in the spaces of (counter-)hegemonic politics of the past or remembrance culture and therefore do not receive a resonance in public space (Eser \& Peters, 2016). ${ }^{13}$

Here, a distinction can be made between political and social reasons for exclusion from the space of legitimate memory narratives. The former focus on interpretations of the past that challenge, irritate or even contradict the (counter-)hegemonic memory narratives. In contrast, the social reasons for exclusion from the legitimate public space of memory - secondly - focus on the social positioning of the emitters of the memory fragments. Accordingly, various determinants of social inequalities (social

12 The manifold struggles for memory make it clear that the space for the articulation of legitimate interpretations of history is often very broad and includes both hegemonic and counter-hegemonic narratives. Especially in democracies, controversies about the past can even be fruitful as an expression of a lively culture of remembrance for the construction of a positive self-image. Positions beyond the legitimate scope of interpretation, on the other hand, are marginalised, stigmatised and sometimes even criminalised. Recent examples include the Armenian genocide in Turkey or the criminalization of supporters of radical Basque nationalism through the criminal offence of 'glorification of terrorism'.

13 This is not necessarily problematic: not all interpretations of the past stand up to historical scrutiny, while in other cases a contextualization at least relativizes the memory narratives. 
class, ethnicity, gender, social-territorial inequalities, age, etc.) and their intersectional entanglements (Viveros Vigoya, 2016) are reflected in the possibility of achieving resonance for articulations of memory narratives.

\section{(Non-)memory through political exclusion}

Political reasons for exclusion from the public space of remembrance are particularly evident in authoritarian regimes or dictatorships. Here, the lack of freedom of the press and freedom of opinion allows for a particularly effective exclusion of unwelcome memories of the past. This applies, for example, to the memory of the murder of opposition politicians in Belarus at the end of the 20th century (FAZ 30-12-2019) or the repression of the memory of the massacre on Tiananmen Square in Beijing in 1989 (Hilpert, Krumbein \& Stanzel, 2019: 6p.; Tiffert, 2019). ${ }^{14}$

Although dictatorships and authoritarian regimes are particularly repressive and rigorous in excluding unwelcome memory narratives from the public space of remembrance and often sanction violations of the official line directly, other forms of politically motivated renunciation of memory can be found in democracies. This can be observed, within the processes of dealing with the past, for example in the selection of the victims' voices. The "quality of voice" (Hamber, 2009: 130) or the importance of a (judicial) case, is usually assessed by experts and, given the quantity of testimonies of victims, necessarily involves a selection process. The selection mechanisms can also be oriented towards questions of political desirability of the victims' positions. This was the case, for example, with the South African Truth and Reconciliation Commission, where the focus on the goal of reconciliation tended to exclude those voices of victims who could not be integrated into this politically motivated goal, or at least

14 Tiffert sums up the exclusion of specific topics from collective memory in the People's Republic of China in the following way: "Thirty years on, media and online references to the protests and their suppression are still banned in the PRC. Zhao Ziyang, the CCP general secretary ousted in the attendant leadership struggle, remains nearly unmentionable. Police harass or arrest those who persist in demanding that the government issue an honest accounting of what happened. Plainclothes officers, intent on forestalling any acts of remembrance, inundate the relevant sites on the relevant anniversaries, supported by ubiquitous cameras capable of facial recognition. The result is coerced public amnesia on an epic scale. With 40 percent of the Chinese population now too young to recollect it personally, this history, so searing to those who experienced it firsthand, risks slipping from the consciousness of a nation" (Tiffert, 2019: 38). 
manoeuvred them into a subordinate position (McEvoy \& McConnachie, 2013: 496p.).

Another example of politically motivated renunciation of memory is the case of the (non-)memory of the ETA assassination of the designated successor to the Spanish dictator Francisco Franco, Luis Carrero Blanco in December 1973. The violent assassination of Carrero Blanco removed the option of the dictatorship's preferred continuation of Francoism without Franco in Spain. At the same time, the assassination contradicts the equally established and comfortable interpretations of the Spanish transition by a large part of Spanish society. According to these interpretations, there was a peaceful and exemplary transition from a dictatorship to a democracy under the auspices of a constitutional monarchy. The fact that a violent assassination of Franco's designated successor acted as a trigger for the Spanish transition at least puts the prevailing interpretation of the past into distress. This unease is further reinforced by the fact that ETA, and with it the military arm of radical Basque nationalism - which broad sections of the population regard as terrorism - has, to put it bluntly, blasted open the door to Spanish democracy. To avoid any misunderstanding, it is not the intention to justify or even glorify the attack on its aftermath. Rather, the example is intended to illustrate how politically uncomfortable elements of the past are excluded or marginalised from the hegemonic memory narrative and thus forgotten or better concealed (Eser \& Peters, 2016).

Another example concerns the so-called 'peaceful revolution' in the former GDR and German reunification. This historic turn of events was debated extensively in 2019 during the celebrations for the 30th anniversary of the fall of the Berlin Wall (Pollack, 2020). The public attention of the round day of remembrance provided space for controversies about the role of the Treuhand or how the well-known slogan 'We are the people' and the Monday demonstrations are dealt with today. Regardless of these controversies, we can also observe a broad consensus: There is vast agreement in politics and society that the end of the GDR and reunification was supported by courageous democrats and allowed "the transition from a society of dictatorship and consumer restrictions to one of political freedom and access to an international labour and consumer market" (Ahbe, 2019: 11). There is no doubt that both the civil rights movement and ordinary people in the GDR played a major role in reunification. This was accompanied by a significant increase in political freedom and a deep economic transformation. However, the focus on the role of courageous democrats outshines the unappetizing side of the presence of neo-fascist groups at demonstrations in the wake of the fall of the Wall and reunification. It is precisely this dark side that is excluded from the interpretation of the past 
by the politics of memory (Farin \& Seidel, 2019: 9). It is no coincidence that Peter Richter (2015), a journalist and writer, illustrates the potential for alternative interpretations of history in his novel 89/90:15 "It could be felt that later, as on 17 June, there would be two versions of history, one by courageous citizens and one by the neo-fascist mob" (Richter, 2015: 207p.; see also: Ahbe, 2019: 12; Farin \& Seidel, 2019; Lierke \& Perinelli, 2020). In his novel, Richter describes the period of upheaval in the years 1989/90 in Dresden from the point of view of a young person and deals with the growing presence of nationalist, fascist and neo-Nazi groups in the GDR and their political significance for the period of change: "Since the fall of the Wall, entire choirs have suddenly been shouting non-stop nothing but: Germany!” (Richter, 2015: 207). Richter draws attention to a part of GDR society and the supporters of unification that is hardly ever heard in today's debate about the 'peaceful revolution' of reunification, both in terms of the politics of the past and the culture of memory: "These were not the demonstrations of a month ago, but two demonstrations in a row. In the front was, so to speak, Germany! and at the back of the front was Groszdeutschland. Freedom of the press, self-determination, democratic GDR and so on ran at the back" (Richter, 2015: 210). Richter's description of the famous speech given by the then Federal Chancellor Helmut Kohl in Dresden on 19 December 1989 is particularly haunting (Richter, 2015: $224 \mathrm{pp}$.). Kohl saw the day as a "key experience" and the reaction to this speech later as a mandate for rapid reunification, while Richter points to the presence of a mob who ranged from German-national to neo-fascist. The Federal Chancellor and his staff were well aware of the nationalist mood in Dresden and wanted to avoid negative images, for example by singing the - prohibited - first verse of the national anthem of the Federal Republic of Germany - also in view of the reactions from Europe, the USA and the Soviet Union, at all costs. ${ }^{16} \mathrm{~A}$ similar approach can be found in the

15 The generic term novel is at least controversial: In his book review, Dietmar Jacobsen calls the text a "semi-fictional report" (https:/literaturkritik.de/id/20521; 31-12-2019).

16 This is by no means about a single (literary) voice: The Austrian journalist Ewald König also recalls the nationalism in the audience: "I [...] stood in the front row in front of the podium [...]. All around me were many tall blond men, who pushed their fists up into the sky and shouted out in a militant rhythm: "Germany! Germany! Germany! Germany!” Twenty years later the echo still gives you goose bumps." (https://www.euractiv.de/section/wahlen-und-macht/news /kohls-balanceakt-in-dresden/; 31-12-2019). And the Hannoversche Allgemeine Zeitung also addresses the tension between democracy and nationalism at the time of the Wende: "He [Helmut Kohl; S.P.] speaks somewhat circumstantially 
interview volume Wendezeit by Klaus Farin and Eberhard Seidel (2019), published by a publisher on the margins. In the introduction, the two authors describe an event from the night of the fall of the Berlin Wall that also has no place in public memory:

"In the middle of the Trabbi caravan, a West Berliner of Turkish origin comes from the eastern part of the city in his VW bus. His appearance disturbs the euphoric crowd, which greets every Wartburg and Trabant with rhythmic clapping. Some faces darken, the singing stops, the clapping stops. In response to the frosty reception he shouts, 'Welcome unemployment' to the crowd. The mood changes. The first of the drunken reception committee kick the VW bus. 'What does he want here?' is still one of the most quotable reactions" (Farin \& Seidel, 2019: 7).

It is not a question of precisely determining or even quantifying the importance of the nationalist and neo-fascist groups within the Monday demonstrations or their relevance for reunification. But they were undoubtedly a factor that shaped the period of change on the streets (Siegler, 1991; Wagner, 2014). ${ }^{17}$ This could be of interest, especially in view of current debates on neo-Nazi structures and/or the electoral successes of the right-wing or even neo-fascist AfD (Alternative für Deutschland) in the former GDR. Accordingly, the focus is on the question why this dark side of the 'peaceful revolution', despite its importance for the streets and its aftermath, is hardly present in German politics of the past, and why it is only occasionally negotiated on the fringes of the culture of remembrance. The various

on this evening of democratization in the GDR, of free elections. But then the first choruses are already being chanted by people who would like it to be more direct: 'Germany, one fatherland! The historic speech [...] marked not only a triumph, but also a problem - for Kohl as well as for the current CDU. From the very beginning, there was tension between the full-bodied national feeling and what a CDU involved in nationwide and worldwide government policy was able to offer them as real politics" (HAZ 29-08-2018). The German national flank was nevertheless wide open under Kohl: After the neo-Nazi attack in Mölln (1992), then Chancellor Kohl refused to attend the funeral service on the grounds that he did not want to fall prey to 'pity tourism' (Jakob, 2016: 10).

17 See, for example, the 27.5.1991 edition of Der Spiegel, which contains a list of neo-Nazi violence in East Germany. In this context, the murder of the student Mahmoud Azhar in March 1990 by drunk GDR citizens, which was accompanied by German nationalist slogans, is worth mentioning (Farin \& Seidel 2019: 11). Moreover, the project $2^{\text {nd }}$ October 1990 is a very important space for documenting the racist and neofascist violence in the context of German reunification: https://zweiteroktober90.de/. 
actors seem to have no interest in addressing this issue, either because they do not want to devalue the success story of reunification through ambivalence, or because they are reluctant to admit that they demonstrated together with fascists, or because they do not want to question the nostalgia of a supposedly intact world of anti-fascism in the GDR. For future research, it would be useful to find out the reasons for the exclusion of this dark side from the memory of the time of reunification. It is important to determine empirically what role the Kohl government played, which did not want to tarnish its political success by addressing neo-Nazi structures, or whether and to what extent the grassroots democratic GDR citizens' movement opposed such thematization, so as not to have to relativize its own role through the ambivalence of the protests in the run-up to reunification. ${ }^{18}$

\section{Social inequalities and (non-)memory}

The forgetting or silencing of certain facets of the past, which lie transverse to the hegemonic and counter-hegemonic narratives of memory, represents only one facet of (non-)memory. It is supplemented by those memories that exist but whose marginalised actors have little or no resonance in the public space. Here it is social factors that make it difficult for these memories to articulate themselves or to make themselves heard in past political and/or memory cultural spaces. Power asymmetries are thus based on social inequalities and the exclusion of certain population groups. Social inequalities must therefore be understood in a multidimensional way, taking into account Bourdieu's reflections on economic, cultural, social and symbolic capital, including not only vertical but also horizontal inequalities and the intertwining of various axes of inequality in line with the approaches of intersectional research (Bourdieu, 1983; Kreckel, 2004; Viveros Vigoya, 2016).

Latin America appears to be a particularly fertile field of investigation for the analysis of the effects of social inequalities and marginalisation on (non-)memory or on the concealment of memory narratives of subaltern population groups. The region is characterized by the common structural feature of extreme and historically persistent social inequalities as well as the aftermath of colonialism with regard to structural discrimination against black and indigenous population groups, an entrenched

18 I would like to thank Markus Ciesielski for this advice on possible explanations. 
patriarchy and strong socio-territorial inequalities (Reygades, 2008; Pérez Sáinz, 2014). In the following, the significance of social inequalities for the presence or absence of memories in Latin America's politics and culture of remembrance will be discussed on the basis of two examples: i) enforced disappearance and ii) the memory of sexual violence.

Cases of violent disappearances of political opponents unfortunately can be found in almost all of Latin America. For the relatives, this form of violence means continued insecurity and the impossibility of a ritual funeral. Nevertheless, the significance of disappearances in collective memory varies considerably from one country to another. In Argentina today, the memory of human rights violations during the civil-military dictatorship (1976-1983) cannot rightly be discussed without focusing on the practice of enforced disappearances. Human rights organisations talk about 30,000 disappeared during the dictatorship, while the National Commission for the Search for Disappeared Persons (Comisión Nacional sobre la Desaparición de Personas, CONADEP), set up immediately after the end of the dictatorship, documented 8,960 disappeared persons in 1984 (Crenzel 2008: 115). In comparison to the other civil-military dictatorships in the Southern Cone (Brazil, Chile, Uruguay), violent disappearances were thus a form of human rights violations against alleged or actual opponents of the dictatorship, especially in Argentina (Peters, 2016).

Nevertheless, Argentina's special role in enforced disappearances is at least debatable in relation to other Latin American countries. To avoid misunderstandings: this is not about a rigorous comparison between different case studies, nor is it about a simple quantification of suffering. Rather, the focus will be on the differences in the social resonance of disappearances in different Latin American countries. In Mexico, according to official figures and in spite of a high number of unreported cases, more than 73,000 victims of enforced disappearances are lamented. ${ }^{19}$ In Colombia, tens of thousands of people also became victims of enforced disappearances during the armed conflict in the country: the Colombian Victims' Registry lists 49,000 disappeared, while the National Remembrance Centre lists more than 82,998 disappeared and also suspects a number of unreported cases (Olarte-Sierra \& Castro Bermúdez, 2019: 122). No attempt will be made here to offset the number of victims. Rather, the crime of enforced disappearance must always be analysed in terms of its social impact, regardless of the numbers involved. This is why it is all the more surprising

19 https://www.eleconomista.com.mx/politica/Segob-reporta-73224-personasdesapar ecidas-en-Mexico-20200713-0064.html (13-09-2020). 
that enforced disappearances in Colombia play at best a subordinate role in dealing with the past. It is true that the peace process also established a 'Unit for the Search of Disappeared Persons' as part of the country's Transitional Justice Instruments. However, this authority was only established under pressure from the victims and has received little public attention to date. It is hardly surprising that the issue of the disappeared is not the focus of remembrance work.

The striking contrast in the public response to the issue of the violently disappeared in the treatment of the past between Argentina and Colombia can be partly explained by the different contexts of violence. In Argentina, a large proportion of those murdered under the dictatorship had been victims of enforced disappearances, while the high number of disappeared in Colombia stands alongside incomparably higher numbers of victims (over 230,000 murdered; approximately 8 million internally displaced persons). In short, these are completely different contexts of violence. However, this explanation alone does not seem sufficient: Behind every violent disappearance there are relatives and friends as victim groups, who at least potentially can raise their voices, demand an investigation of the crimes and maintain the public memory of their relatives. However, this happens much more frequently in Argentina than in Colombia, for example, and the public presence in Argentina is unequal. In order to come closer to an explanation for the comparatively low presence of enforced disappearances in Colombia, it is necessary - according to our argument - to take greater account of the social composition of the victim groups. In Colombia, the victims of enforced disappearances are generally left-wing political activists and - as a study on disappearances in Buenaventura on the Colombian Pacific coast has shown - people "with low incomes" (CNMH, 2015: 227; see also: Sánchez, 2016: 17; Aranguren, 2020). This predominant picture is also confirmed by a recently discovered mass grave in Dabeiba in the Colombian province of Antioquia. At the behest of the Colombian Special Jurisdiction for Peace (Jurisdicción Especial para la Paz, JEP), exhumations of disappeared bodies of so-called falsos positivos are being carried out here. The victims are young people from the poor outskirts of the city of Medellín, poor rural dwellers, homeless people and people with disabilities (Semana 15-12-2019). In short, these are groups of victims who, due to their marginalised social position, hardly have a voice to effectively denounce the crimes or find a resonance in the urban debate on dealing with the past. In contrast, a large proportion of the victims of disappearances during the civil-military dictatorship in Argentina came from the urban middle class and often belonged to the student milieu. Their relatives therefore had different social conditions to make their voices heard in the 
debate on memory. The social position is thus a (often forgotten) factor in explaining which crimes of the past are present in the debate on the past and on the culture of memory.

This pattern is confirmed by the presence of memories of female victims of sexual violence in the context of armed conflict. In 2017, the Centro Nacional de Memoria Histórica reported the number of 15,076 victims of sexual violence in the context of the armed conflict (CNMH, 2017), while the Unidad para las Victimas registered 26,534 victims of sexual violence by 2019. Especially with this form of violence, a high number of unreported cases must be assumed. In particular women and girls from the remote areas of the country and often Afro-Colombian or indigenous communities became victims of this violence by paramilitary groups, guerrilla groups and the military (Rivera Revelo, 2020). As a rule, however, these women are nameless victims, and the documented cases disappear into archives or into well-researched but hardly publicly perceived reports.

An exception is the case of the famous Colombian television journalist Jineth Bedoya. Bedoya became a victim of sexual violence by paramilitary groups, made these crimes public and was thus able to draw public attention to sexual violence in the context of the armed conflict. The day on which she became a victim of sexual violence was declared in 2014 by the then President Juan Manuel Santos as the national day of dignity for women who were victims of sexual violence in the context of the armed conflict, following a petition by a women's group around Bedoya.

There is no doubt that Bedoya's addressing of the violence suffered and her subsequent commitment to victims of sexual violence is an important contribution to the victims and to the memory of an often-silenced topic of violence. Nevertheless, it is evident that it was a woman from the upper middle class, with a high profile and rich cultural and social capital, who - after a protracted struggle and with the help of international support positioned the subject in the public eye. By contrast, a large proportion of victims come from socially disadvantaged groups and are sometimes denied access to justice, particularly to the public and to the authorities of legitimate (remembrance) culture (Rivera Revelo 2019). Here too, social inequalities explain who has a voice in the debate on violence and who is heard or silenced - or even forgotten.

\section{Conclusions}

Collective memory processes do not have magical abilities and are therefore no guarantee for a more peaceful future. This insight is banal, yet 
it runs counter to the widespread enthusiasm for memory (Daly, 2008). However, to deduce from this a plea for forgetting or for the renunciation of measures for collective remembrance seems problematic not only in normative terms. Various empirical examples from the past also suggest that political and/or social agreements regarding the hushing-up of past violence are repeatedly caught up in reality and are often followed by a particularly intensive examination of the violent past (Pollak, 2006: 20). But above all, sweeping praise of the healing power of forgetting, the central question of the groups responsible for the decision to remember or forget, and the consequences of forgetting for different social groups are ignored: In this line there is need for new approaches. "The crucial question must always be: who profits, who suffers from forgetting? (Assmann, 2012: 68; see also: Sosa González \& Mazzucchi Fereira, 2012: 893). While the victims must be granted a right not to talk about the past, they also have a right to bring their suffering and grief into processes of collective memory. In other words: Silence must be a choice chosen, not a state enforced. Exclusion from the public space of remembrance can be politically motivated and/or have their origins in structural inequalities. What both cases have in common is that forgetting or remaining silent is unintentional. In these cases, forgetting in collective memory is contrasted with painful memories in individual or social memory.

There is often an academic concern to feed these hidden, "subterranean memories" (Pollak 2006: 18) into the collective memory and make them visible. In view of the lack of resources (material, cultural, social and/or symbolic), however, these aspirations are disappointed time and again. It is precisely here that art, culture and science can contribute to increasing the visibility of marginalised memories by positioning them at the heights of legitimate culture. This is presuppositional for various reasons: On the one hand, there is the theoretical and methodological problem of the (possibility of) representing the memories of subaltern groups by privileged actors and the pitfalls associated with this. Thus, it seems hardly avoidable that the narrative of memory experts does not reflect the voice of the victims or witnesses - but rather a version adapted to the requirements of memory politics (hooks, 1990; Spivak, 1998; Ruiz, 2020). On the other hand, there is the empirical or pragmatic challenge that the forgotten or hushed up memories must first be discovered in order to enable scholars to subsequently analyse the mechanisms of (non-)memory - understood as silence, repression or forgetting - and/or to be able to make these memories visible in the public space of legitimate culture (Peters, 2015). At best, the latter can, in cooperation with historically disadvantaged social 
groups, promote the presence of their memories in the public space and thus contribute to a change in interpretations of the past.

However, the analysis of (non-)memory is not only politically relevant, but also academically promising. The academic gain of analysing processes of (non-)remembrance is thus not limited to supplementing the cartography of a society's memory landscape with aspects beyond the legitimate culture and official politics of the past. The systematic analysis of (non-)memory makes it possible to track down uncomfortable and/or marginalised memories that stand perpendicular to the established narratives about the past. In a further step, the empirical analysis of the processes of concealment or exclusion of these subterranean memories can be used to make further statements about the mode of construction of (counter)hegemonic memories and exclusion mechanisms of marginalising interpretations of the past. In this way, in many cases the strengthening of the perspective of inequality can be productively intertwined with the promotion of analyses of the (non-)memory of events and processes of the past in order to analyse the manifestation of social power relations in memory processes.

\section{Bibliography}

Aguilar, Paloma (2002): Memory and Amnesia: The Role of the Spanish Civil War in the Transition to Democracy. Oakley: Berghahn Books.

Ahbe, Thomas (2019): Revolution und Vereinigung: Viele Erfahrungen und eine große Erzählung. In: Politische Bildung 4/2019, 10-17.

Alarcón, Diego (2020): La batalla por la memoria. In: Arcadia 171, 12-17.

Alier Montaño, Eugenia (2018): Tlatelolco, lugar de memoria y sitio de turismo: Miradas desde el 68. In: Revista Mexicana de Ciencias Políticas y Sociales, 63 (234), 215-238.

Alier Montaño, Eugenia (2010): Batallas por la memoria. Los usos políticos del pasado reciente en Uruguay. Montevideo: Trilce.

Allier Montaño, Eugenia \& Crenzel, Emilio (2016): Las luchas por la memoria en América Latina: Historia reciente y violencia política. México: Universidad Nacional Autónoma de México-Instituto de Investigaciones Sociales/Bonilla Artigas Editores/Iberoamericana Vervuert.

Aranguren, Juan Pablo (2020): Impactos psicosociales de la impunidad en casos de desaparición forzada y ejecuciones extrajudiciales en Colombia. Speech at the Conference "Represión política, desaparición forzada y estrategias de resilencia en contextos de desigualdad" Maria Sibylla Merian Center for Advanced Latin American Studies (CALAS) in Guadalajara, 26.2.2020. 
Assmann, Aleida (2012): To Remember of to Forget: Which Way Out of a Shared History of Violence? In: ibid. \& Linda Shortt (Eds.): Memory and Political Change. London: Palgrave Macmillan, 53-71.

Assmann, Aleida (2016): Formen des Vergessens. Berlin: Suhrkamp.

Bajohr, Frank, Drecoll, Axel \& Lennon, John (2020): Dark Tourism: Reisen zu Stätten von Krieg, Massengewalt und NS-Verfolgung. Berlin: Metropol.

bell hooks (1990): Yearning: Race, Gender, and Cultural Politics. Cambridge: South End Press.

Bernecker, Walther L. \& Brinkmann, Sören (2006): Kampf der Erinnerungen. Der Spanische Bürgerkrieg in: Politik und Gesellschaft 1936-2006. Nettersheim: Verlag Graswurzelvolution.

Bock, Petra \& Wolfrum, Edgar (1999): Einleitung. In: ibid. (Eds.): Umkämpfte Vergangenheit: Geschichtsbilder, Erinnerung und Vergangenheitspolitik im internationalen Vergleich. Göttingen: Vandenhoeck \& Ruprecht, 7-15.

Bourdieu, Pierre (1983): Ökonomisches, kulturelles und soziales Kapital. In: Kreckel, Reinhard (Ed.): Soziale Ungleichheiten. Göttingen: Schwartz \& Co, 183-198.

Buckley-Zistel, Susanne \& Oettler, Anika (2011): Was bedeutet: Transitional Justice? In: Buckley-Zistel, Susanne \& Kater, Thomas (Eds.): Nach Krieg, Gewalt und Repression. Baden-Baden: Nomos, 21-37.

Capdepón, Ulrike (2018): Die späte Auseinandersetzung mit der Franco-Vergangenheit. In: Mihr, Anja, Pickel, Gert \& Pickel, Susanne (Eds.): Handbuch Transitional Justice: Aufarbeitung von Unrecht - Hin zur Rechtstaatlichkeit und Demokratie. Berlin: Springer, 275-293

Castiñeira, Ángel (2005): Naciones imaginadas. Identidad personal, identidad nacional y lugares de memoria. In: Resina, Joan Pablo \& Winter (Eds.): Casa encantada. Lugares de memoria en la España constitucional (1978-2004). Frankfurt (Main): Vervuert, 41-77.

Clair, Robin Patric (1998): Organizing Silence: A World of Possibilities. Albany: State University of New York Press.

CNMH (2015): Buenaventura: Un Puerto sin Comunidad. Bogotá: CNMH.

CNMH (2017): La Guerra inscrita en el cuerpo: Informe Nacional de Violencia en el Conflicto Armado. Bogotá: CNMH.

Cohen, Stanley (1995): States of Denial: Knowledge, Accountability, and the Policing of the Past. In: Law and Social Inquiry, 20 (1), 7-50.

Connerton, Paul (2008): Seven Types of Forgetting. In: Memory Studies 1 (1), 59-71.

Crenzel, Emilio (2008): La historia política del Nunca Más: La memoria de las desapariciones en la Argentina. Buenos Aires: Siglo XXI.

Daly, Erin (2008): Truth Skepticism: An Inquiry into the Value of Truth in Times of Transition. In: International Journal of Transitional Justice, 2 (1), 23-41.

Dimbath, Oliver \& Wehling, Peter (2011): Soziologie des Vergessens: Konturen, Themen und Perspektiven. In: ibid. (Eds.): Soziologie des Vergessens. Theoretische Zugänge und empirische Forschungsfelder. Konstanz: Halem, 7-34. 
Eser, Patrick \& Peters, Stefan (2016): El atentado contra Carrero Blanco como lugar de (no-)memoria: Narraciones históricas y representaciones culturales. Madrid: Iberoamericana.

Farin, Klaus \& Seidel, Eberhard (2019): Wendejugend. Berlin: Hirnkost.

Figari Layús, Rosario, Krüger, Annegret \& Peters, Stefan (2021): Friedens- und Konfliktforschung in Lateinamerika: Ein Überblick. In: Lay-Brandner, Miriam (Ed.): Einführung in die Lateinamerikastudien. Berlin: Erich Schmidt Verlag. Fortcoming.

Förster, Annette (2008): Ja zur Folter - Ja zum Rechtsstaat? Wider die Relegitimierung der Folter in Deutschland. In: Biegi, Mandana et al. (Eds.): Demokratie, Recht und Legitimität im 21. Jahrhundert. Wiesbaden: VS Verlag, 111-127.

Fuchs, Ruth (2010): Umkämpfte Geschichte. Vergangenheitspolitik in Argentinien und Uruguay. Münster: LIT.

González Vazquez, David \& Mundet i Cerdan, Lluis (2018): Lugares de memoria traumática y turismo: paradigma analíticos y problemáticas. In: Revista Investigaciones Turísticas, 16, 108-126.

Gutiérrez, Carlos Arturo (2019): De víctimas a pedagogas de la memoria: el caso de las llamadas Madres de Soacha. In: Controversia 213, 229-262.

Halbwachs, Maurice (1985): Das Gedächtnis und seine sozialen Bedingungen. Frankfurt (Main): Suhrkamp.

Hamber, Brandon (2009): Transforming Societies after Political Violence. New York: Springer.

Hilpert, Hanns Günther, Krumbein, Frédéric \& Stanzel, Volker (2019): Chinas gelenkte Erinnerung: Wie historische Ereignisse erinnert, glorifiziert, umgedeutet und verschwiegen werden. In: SWP Aktuell 70. Berlin: SWP.

Hite, Katherine (2017): Spaces, Sites and the Art of Memory. In: Latin American Research Review, 52 (1), 190-196.

Jakob, Christian (2016): Die Bleibenden: Wie Flüchtlinge Deutschland seit 20 Jahren verändern. Berlin: Ch.Links.

Jarab, Jan (2019) Presentación. In: Comisión Nacional de los Derechos Humanos/ Oficina en México del Alto Comisionado de las Naciones Unidas para los Derechos Humanos (Eds.): La desaparición forzada en México: Una mirada desde los organismos del sistema de Naciones Unidas. México, 15-17.

Jelin, Elisabeth (2017): La lucha por el pasado: Cómo construimos la memoria social. Buenos Aires: Siglo XXI.

Jelin, Elisabeth (2002): Los trabajos de la memoria. Madrid: Siglo XXI.

Jelin, Elisabeth (2015): Erinnerung und Demokratie: Eine ungewisse Beziehung.

In: Peters, Stefan, Burchardt, Hans-Jürgen \& Öhlschläger, Rainer (Eds.): Geschichte wird gemacht: Vergangenheitspolitik und Erinnerungskultur in Lateinamerika. Baden-Baden: Nomos, 19-36.

Judt, Tony (2005): Postwar. A History of Europe since 1945. London: Penguin. 
Karstedt, Susanne (2010): From Absence to Presence, From Silence to Voice: Victims in International and Transitional Justice since the Nuremberg Trials. In: International Review of Victimology, 17, 9-30.

Kohlstruck, Michael (2004): Erinnerungspolitik: Kollektive Identität, Neue Ordnung, Diskurshegemonie. In: Schwelling, Birgit (Ed.): Politikwissenschaft als Kulturwissenschaft. Wiesbaden: Springer, 173-193

Kreckel, Reinhard (2004): Politische Soziologie sozialer Ungleichheiten. Frankfurt (Main): Campus.

Krüger, Anne K. \& Scheuzger, Stephan (2019): Die globale Verbreitung von Wahrheitskommissionen als Instrument der Transitional Justice. In: Mihr, Anja, Pickel, Gert \& Pickel, Susanne (Eds.): Handbuch Transitional Justice. Wiesbaden: Springer.

Leggewie, Claus (2011): Der Kampf um die europäische Erinnerung: Ein Schlachtfeld wird betrachtet. München: C.H. Beck.

Lessa, Francesca (2011): 'No hay que tener los ojos en la nuca': The memory of violence in Uruguay, 1973-2010. In: ibid./Druliolle, Vincent (Eds.): The Memory of State Terrorism in the Southern Cone: Argentina, Chile and Uruguay. New York: Palgrave, 179-208.

Lessa, Francesca (2014): ¿Justicia o impunidad? Cuentas pendientes en el Uruguay post-dictadura. Montevideo: Penguin.

Lierke, Lydia \& Perinelli, Massimo (2020): Erinnern stören: Der Mauerfall aus migrantischer und jüdischer Perspektive. Berlin: Verbrecher Verlag.

Lübbe, Hermann (1983): Der Nationalsozialismus im politischen Bewusstsein der Gegenwart. In: Broszat, Martin, Dübber, Ulrich \& Hofer, Walther (Eds.): Deutschlands Weg in die Diktatur. Berlin: Siedler, 329-349.

Mannergren Selimbergovic, Johanna (2020): Gendered silences in post-conflict societies: a typology. In: Peacebuilding, 8 (1), 1-15.

McEvoy, Kieran \& McConnachie, Kirsten (2013): Victims and Transitional Justice: Voice, Agency and Blame. In: Social \& Legal Studies, 22 (4), 489-513.

Meier, Christian (2010): Über das Gebot zu Vergessen und die Unabweisbarkeit des Erinnerns: Vom öffentlichen Umgang mit schlimmr Vergangenheit. Berlin: Siedler.

Olarte-Sierra, María Fernanda \& Castro Bermúdez, Jaime Enrique (2019): Notas forenses: conocimiento que materializa a los cuerpos del enemigo en fosas paramilitares y falsos positivos. In: Antípoda 34 (1), 119-140.

Olaso, Julieta (2016): La represión y las luchas por la memoria en Argentina y España. Barcelona: La Catarata.

Payne, Leigh \& Bilbija, Ksenija (2011): Accounting for Violence: Marketing Memory in Latin America. Durham: Duke University Press.

Pérez Sáinz, Juan Pablo (2014): Mercados y bárbaros: la persistencia de la desigualdad del excedente en América Latina. San José: FLACSO. 
Peters, Stefan (2015): Die Zukunft der Vergangenheit in Lateinamerika, in: ibid., Burchardt, Hans-Jürgen \& Öhlschläger, Rainer (Eds.): Geschichte wird gemacht. Vergangenheitspolitik und Erinnerungskulturen in Lateinamerika. Baden-Baden: Nomos, 185-197.

Peters, Stefan (2016): Die Erinnerung an die zivil-militärischen Diktaturen im Cono Sur: Argentinien in vergleichender Perspektive. In: Eser, Patrick \& Witthaus, Jan-Henrik (Eds.): Memoria-Postmemoria: Die argentinische Militärdiktatur (1976-1983) im Kontext der Erinnerungskultur. Frankfurt (Main): Peter Lang, 13-40.

Pollack, Detlef (2020): Das unzufriedene Volk: Protest und Ressentinment in Ostdeutschland von der friedlichen Revolution bis heute. Bielefeld: transcript.

Pollak, Michel (2006): Memoria, olvido y silencio. La Plata.

Renan, Ernest (1995): Was ist eine Nation? In:. ibid: Was ist eine Nation? Und andere politische Schriften. Wien: Folio, 41-58.

Reygades, Luis (2008): La apropiación: Destejiendo las redes de la desigualdad. México: Anthopos.

Richter, Peter (2015): 89/90. München: Luchterhand.

Ricoeur, Paul (2004): Gedächtnis, Geschichte, Vergessen. München: Fink Wilhelm.

Rieff, David (2016): In Praise of Forgetting: Historical Memories and its Ironies. New Haven: Yale University Press.

Rieff, David (2011): Against Remembrance. Carlton: Penguin.

Rivera Revelo, Laura \& Peters, Stefan (2017): Desigualdades sociales, justicia transicional y posconflicto en Colombia. In: ADLAF (Ed.): Violencia y desigualdad. Buenos Aires: Nueva Sociedad, 79-96.

Rivera Revelo, Laura (2020): Acceso a la justicia: El caso de las mujeres awá víctimas de violencia sexual en el marco del conflicto armado colombiano, Quito. UASB: PhD Thesis.

Roht-Arriazas, Naomi (2006): The new landscape of transitional justice. in: ibid. \& Mariezcurrena, Javier (Eds.): Transitional Justice in the Twenty-First Century: Beyond Truth versus Justice. Cambridge: Cambrdige University Press, 1-16.

Rosa, Hartmut (2016): Resonanz: Eine Theorie der Weltbeziehung. Berlin: Suhrkamp.

Ruiz, Gabriel (2020): Lo cercano y lo lejano. Memorias locales y configuración de narraciones conmemorativas. Un caso de estudio en Colombia. CAPAZ Working Paper. Bogotá: CAPAZ.

Sánchez, Gonzalo (2016): Introducción. In: CNMH: Hasta encontrarlos: El drama de la desaparición forzada en Colombia. Bogotá: CNMH.

Schelotto, Magdalena (2017): El Cambio en Paz: La transición uruguaya y la influencia del modelo español. In: Valim Mansan, Jaime, Yaffé, Jaime \& Gordim da Silveira, Helder (Eds.): Transições à democracia: Europa y América Latino no século XX. Porto Alegre: EdiPucrs.

Siegler, Bernd (1991): Auferstanden aus Ruinen: Rechtsextremismus in der DDR. Berlin: Edition Tiamat. 
Sosa González, Ana María \& Mazzucchi Ferreira, Maria Leticia (2012): Derecho de memoria y búsqueda de verdad: Un estudio comparativo entre Brasil y Uruguay. In: Diálogos 16 (3), 873-896.

Tiffert, Glenn (2019): Thirty Years after Tiananmen: Memory in the Era of Xi Jinping. In: Journal of Democracy 30 (2), 38-49.

Viveros Vigoya, Mara (2016): La interseccionalidad: una aproximación situada a la dominación. In: Debate Feminista 52, 1-17.

Wagner, Bernd (2014): Rechtsradikalismus in der Spät-DDR: Zur militant-nazistischen Radikalisierung. Wirkungen und Reaktionen in der DDR-Gesellschaft. Berlin: edition widerschein.

Wilches, Ivonne (2010): Lo que hemos aprendido sobre la atención a mujeres víctimas de violencia sexual en el conflicto armado colombiano. In: Revista de Estudios Sociales 36, 86-94. 
